\title{
Developing and Applying Water Security Metrics in China: Experience and Challenges
}

Fu Sun ${ }^{1,2}$, Chad Staddon ${ }^{3}$, Minpeng Chen ${ }^{4,5}$

\section{Addresses}

${ }^{1}$ School of Environment, Tsinghua University, Beijing 100084, China

${ }^{2}$ Asia-Pacific Center for Water Security, Tsinghua University, Beijing 100084, China

${ }^{3}$ Department of Geography and Environmental Management, University of the West of England, Bristol, BS16 1QY, UK

${ }^{4}$ Institute of Environment and Sustainable Development in Agriculture, Chinese Academy of Agricultural Sciences, Beijing 100081, China

${ }^{5}$ Key Laboratory for Agricultural Environment, Ministry of Agriculture, Beijing 100081, China

Corresponding author: Fu Sun (sunfu@tsinghua.edu.cn) 


\begin{abstract}
Water security has gained increasing attention of the whole society since the late 1990s in China, and in recent years its strategic significance for the country has been addressed by the central government more frequently. Indicators characterizing the major components of water security, such as socio-economic conditions, water resources, water environment, and aquatic ecosystems, have been used to develop metrics and measure China's water security status and its progress at different scales of the country, provinces, cities, and river basins since the early 2000s. Aiming at providing sound decision-making, however, there are still critical methodological challenges to this decade-long practice, for example, selection, banding and aggregation of indicators, and consideration of stakeholder participation.
\end{abstract}

\title{
Introduction
}

With the largest population in the world, China is endowed with low water availability per capita, less than one quarter of the global average, and furthermore the limited water resources are unevenly distributed in both space and time [1]. China's water scarcity has been further exacerbated by the rapid socio-economic development as well as the insufficient use, wastage and pollution of water resources during this process in the recent decades [1,2]. The concept of water security emerged in China in the late 1990s to address all the water-related issues and concerns, e.g. safe drinking water, water scarcity, water pollution, and flooding, in an integrated framework [3], and it has gained increasing attention of the whole society including the government, academia, industries, and so on.

At its fifth session in March 2014, the Leading Group for Financial and Economic Affairs (LGFEA) of the Central Committee of the Communist Party of China (CPC), which leads and supervises economic work of both the CPC Central Committee and the State Council, discussed water security issues specifically. In April 2014, the CPC National Security Commission announced at its first session the strategic goal to establish a national security system, including ecological security and resource security which were closely related to water security. In October 2015, an Implementation Plan for the National Water Security Innovation Program was promulgated jointly by several ministries to promote innovation and entrepreneurship for water security and large-scale application of the output of research and development programs for water security. Most recently, strengthening water security has become a major task for developing modern infrastructure during the period of China's $13^{\text {th }}$ five-year plan.

With the rising priority of water security and the implementation of specific policies and programs, it is imperative for China to develop the concept of water security into meaningful metrics, which is also an ongoing global process [4,5], and therefore measure China's water security status and its progress. To this end, this paper will present a review on the practice of developing and applying water security metrics in China, and identify the major experience, challenges, and future research needs in this respect. More than 230 publications with the subject of "water security" from both international and Chinese sources since the late 1990s were reviewed unbiasedly in this study, and around 160 were found to have developed or applied water security metrics and thus laid the basis 
for the following analysis and discussion. It is also worthy to note that, among these 160 publications, almost all the authors are from China, and moreover publications from Chinese sources are 10 times more than those from international sources.

\section{Definition of water security in the Chinese context}

Chinese scholars usually defined "water security" as a state (and a capability) of sustainable utilization of water resources, adequate in both quantity and quality, for human well-being, socio-economic development and ecological conservation, and an acceptable level of risk of water-related disasters [6-13]. The key elements to water security in these definitions are similar to those defined by international institutions and researchers, e.g. Global Water Partnership [14], Asian Development Bank (ADB) [15], United Nations University [16], and Grey and Sadoff [17]. Since people have different perceptions of the adequacy of water quantity and quality and the acceptability of risk, Cheng et al. [7] argued that public perception of water security should also be part of the concept in addition to physical water security, which raised the same issue as discussed by OECD when developing a risk-based approach to water security [18]. Most recently, researchers from the Development Research Center (DRC) of the State Council, a major think-tank of the central government of China, have added peaceful and stable international relationships, with respect to transboundary rivers, to their definition of water security at the national level [19]. Similar concern over the impact of transboundary rivers on water security has also been discussed by international publications, e.g. [16,20]. Therefore, Chinese researchers generally share the same understanding of water security as their international peers.

\section{Development of water security metrics in China}

Metrics have been developed in China to measure water security status at various levels of the country, regions, provinces, cities and river basins $[6,11,12,21,22]$, characterize the temporal dynamics and spatial disparities of water security of the studied region [6,23], and identify the causes of poor water security and the priorities and constraints to improve water security for decision-making [11,21]. Indicators are used to quantify the multiple components, or key dimensions (KDs) as defined by van Beek and Arriens [5], of water security and their corresponding targets, e.g. drinking water safety, clean water environment, and healthy aquatic ecosystems. The reviewed studies on measuring China's water security could generally be classified into three categories, as shown in Table 1, depending on the extent to which they utilized indicators. The first one is descriptive studies that elaborate every KD of water security with quantitative indicators. For example, Jiang [2] characterized China's water security with regard to water availability, water use patterns, wastewater generation and pollution management, water institutions and management, and health of aquatic systems and societal vulnerability. The second category, which constitutes more than $90 \%$ of the reviewed studies and will be discussed below in detail, establishes an indicator system of water security based on selected indicators for each KD and then aggregates them into a composite index. The third category usually builds on the second one and uses quantitative models to link the indicators of water security with the drivers from natural processes and human activities and simulate water security status in different scenarios. For example, several studies [21,22,24,25] developed system dynamics models to 
simulate regional water security in different socio-economic scenarios and proposed optimal development pathways or solutions to enhance water security. If the models are applied in a reverse way, the upper limits of socio-economic drivers, e.g. population and industries, could be determined subject to the constraints of water security indicators. This is the fundamental idea of the "carrying capacity" concept, which has also been proposed as a measurement of water security by some researchers, e.g. Xia and Zhu [26].

Table 1 Three categories of studies on water security metrics in China

\begin{tabular}{clc}
\hline Category & \multicolumn{1}{c}{ Description } & Representative references \\
\hline I & $\begin{array}{l}\text { Studies that developed quantitative indicators to } \\
\text { characterize the key elements of water security }\end{array}$ & {$[2,3]$} \\
II & $\begin{array}{l}\text { Studies that established an indicator system to } \\
\text { derive an aggregated water security index }\end{array}$ & {$[10-12,27-50]$} \\
III & $\begin{array}{l}\text { Studies that not only developed water security } \\
\text { indicators but also predicted their future trend }\end{array}$ & {$[6,21,22,24,25,51-55]$} \\
\hline
\end{tabular}

Among those water security studies that established indicator systems, i.e. the second and third category, around $70 \%$ framed their indicator systems based on 2 to $7 \mathrm{KDs}$ of water security, and the occurring frequencies of the KDs in these studies are shown in the word cloud graph in Figure 1. The more frequently a KD occurs, the larger its size is in the figure. The socio-economic dimension was included in all the reviewed studies, and various indicators were selected to characterize, among others, the drivers of water demand and wastewater discharge, water productivity of different economic sectors, public attitude and response toward water issues, and socio-economic capacity to cope with and recover from water-related disasters. Water resources were a $\mathrm{KD}$ of water security in around $80 \%$ studies and indicators quantifying the availability and abstraction of water resources were considered. Water environment was regarded as a $\mathrm{KD}$ to characterize the quality of water resources and involved in $68 \%$ of the existing studies. Drinking water, water-related ecosystems, water governance, and water-related disasters were also frequently occurring KDs in $30 \%$ to $40 \%$ studies. Taking account of the nexus between water and food, $22 \%$ studies also defined food security as a KD. Last but not the least, researchers $[13,19]$ from the DRC of the State Council proposed water infrastructure and international relationships as KDs of water security. The KD definitions in the water security studies in China are similar to, though not completely the same as, those in the international literature. In comparison with the framework of Asian Water Development Outlook (AWDO) 2013 proposed by ADB [15], for example, drinking water is regarded as a component in both household water security (KD1) and urban water security (KD3), water resources and water-related ecosystems are considered in economic water security (KD2) and environmental water security (KD4) respectively, while resilience to water-related disasters is the fifth $\mathrm{KD}$. 


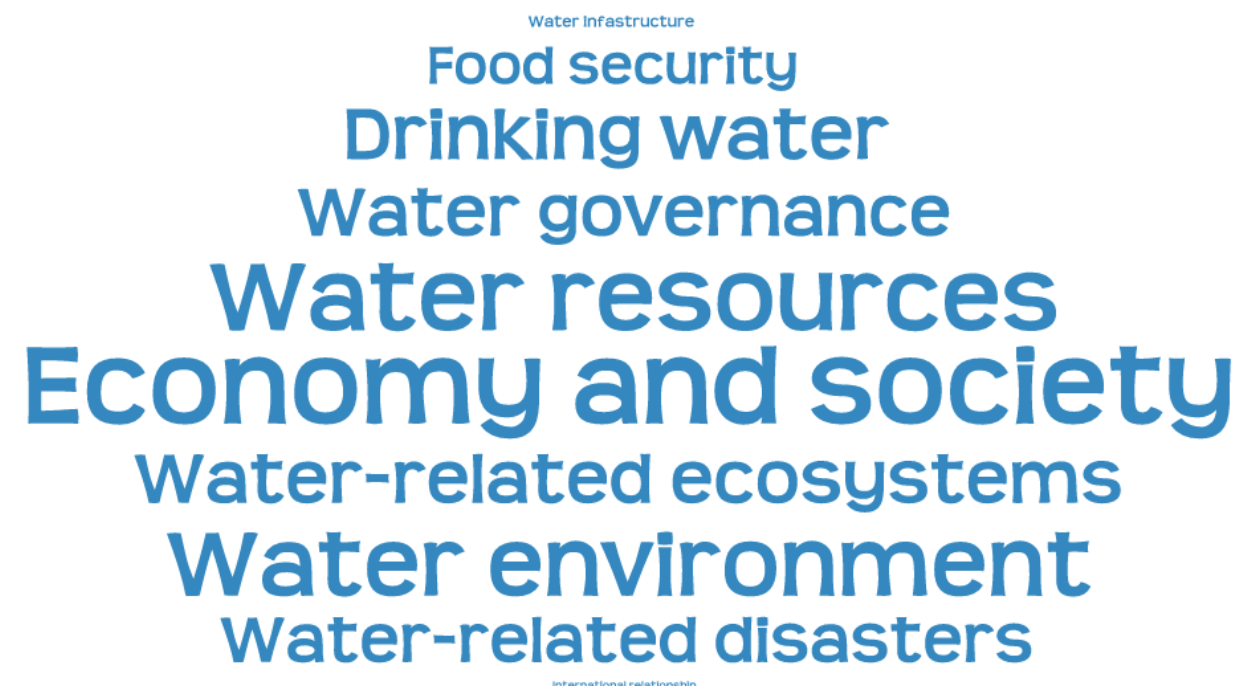

Figure 1 Word cloud of the key aspects involved in the indicator systems for water security

Besides the KD approach, around a quarter of existing studies adopted a "Pressure-State-Response" (PSR) framework [11,27-29] or a full "Driver-Pressure-State-Impact-Response" (DPSIR) framework [30,31] to establish their indicator systems for water security assessment. For example, Liu et al. [31] developed an indicator system, following the DPSIR framework, to measure the water security status of Zhangye region in the northwest of China, and each of the "Driver", "Pressure", "State", "Impact" and "Response" sections consisted of three or four indicators. Quite some studies combined the causal framework with the KD approach and in each section of the framework the indicators were organized according to their related KDs. For example, in Jin and Gong's indicator system [28], the "Pressure" section was further divided into four subsections, i.e. pressure on water resources and water environment and pressure from socio-economic development and floods (or droughts). Water poverty index (WPI) [56,57] was also used to frame indicator systems for water security in several studies, and indicators were selected to quantify each of the five components of the WPI, i.e. resources, access, capacity, use and environment $[10,32,33]$. In addition, the concept of virtual water was introduced to water security assessment by several researchers to reflect the dependency of a region on imported water resources embedded in food and other commodities [34,51].

As shown in Figure 2, the number of indicators selected for water security assessment in the reviewed studies ranged from 6 up to 106, while $92 \%$ of the studies had less than 30 indicators. There always exists a compromise between having a sufficiently large number of indicators to characterize water security comprehensively and having a small enough number of indicators that can be easily obtained. Some researchers suggested that a water security index should ideally have no more than 12 to 15 sub-indicators, and an index with more than 20 sub-indicators may only be applicable to data-rich areas [20]. The number of indicators in most of the current studies as shown in Figure 2, though larger than the proposed ideal number [20], is still reasonable, and furthermore these indicators are practically available from official databases of public access in China. 


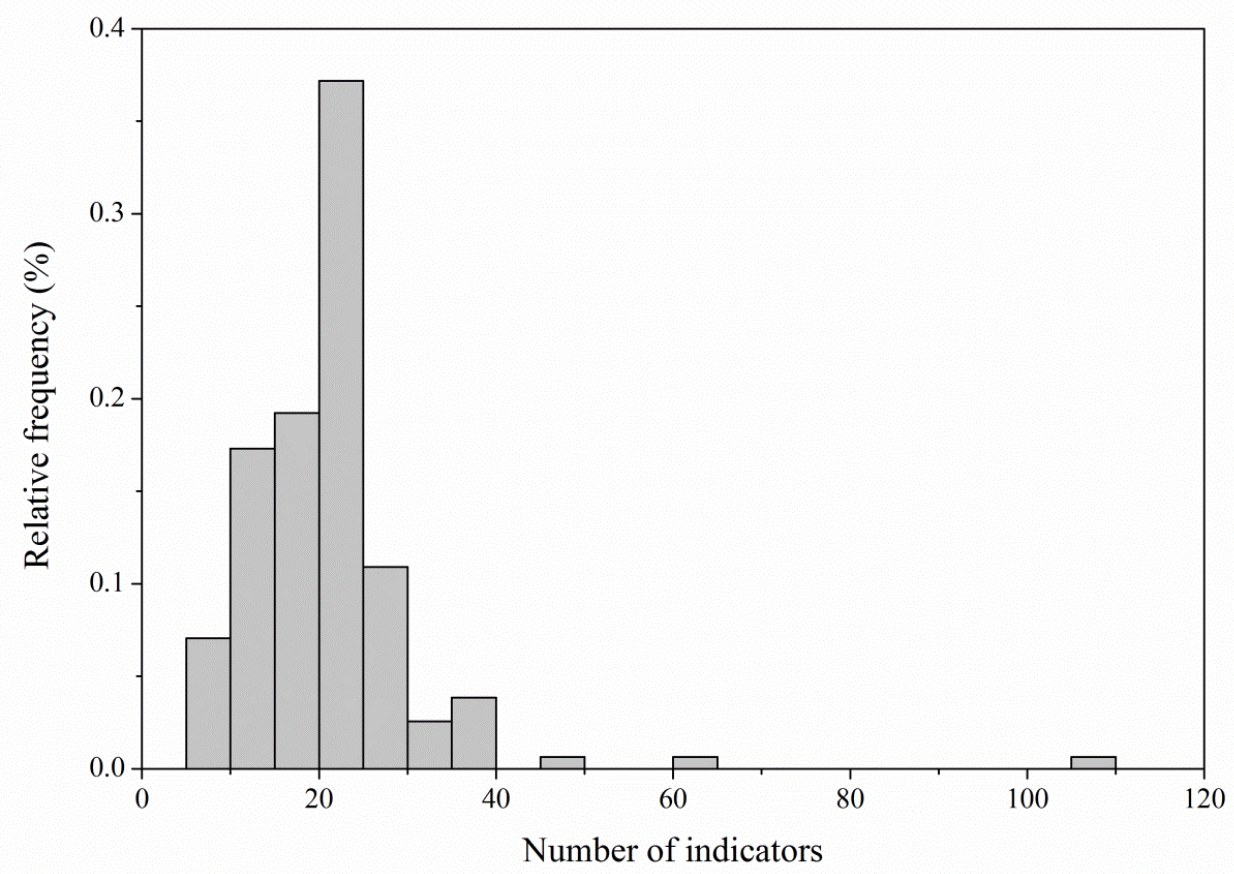

Figure 2 Number of indicators for water security assessment

A further statistical analysis of the indicators resulted in Figure 3, in which the indicators selected by at least a quarter of the reviewed studies were ranked in the order of their occurring frequencies. Figure 3 indicates that the total amount of renewable water resources was used in all the studies to quantify the natural endowment of water resources of a region. Since economy and society was a common KD for water security assessment, socio-economic indicators were among the most frequently selected ones, such as gross domestic product (GDP), investment in water conservancy projects, and population. Utilization of water resources was usually characterized by water demand and withdrawal in total or by sector and other relevant indicators, e.g. grain yield and recycling of industrial water. Damages of floods and droughts and quality of flood control infrastructure were frequently used to quantify the economic loss of and resilience to water-related disasters, while surface water quality and indicators characterizing wastewater discharge were used to represent the state and pressure of water environment. Indicators for drinking water safety and water-related ecosystems were also among the most frequently occurring ones, such as access rate of piped water supply and coverage of forests. It is worthy to note that most of these indicators are applicable worldwide rather than country-specific. For example, AWDO 2013 involved, among others, many indicators listed in Figure 3, such as the total renewable water resources, GDP, industrial water withdrawal, damages of flooding, population, irrigated agricultural land, percentage of treated domestic wastewater, and coverage of piped water supply [20]. Therefore, the indicators developed by Chinese researchers have been used by their international peers for reference, e.g. [58]. 


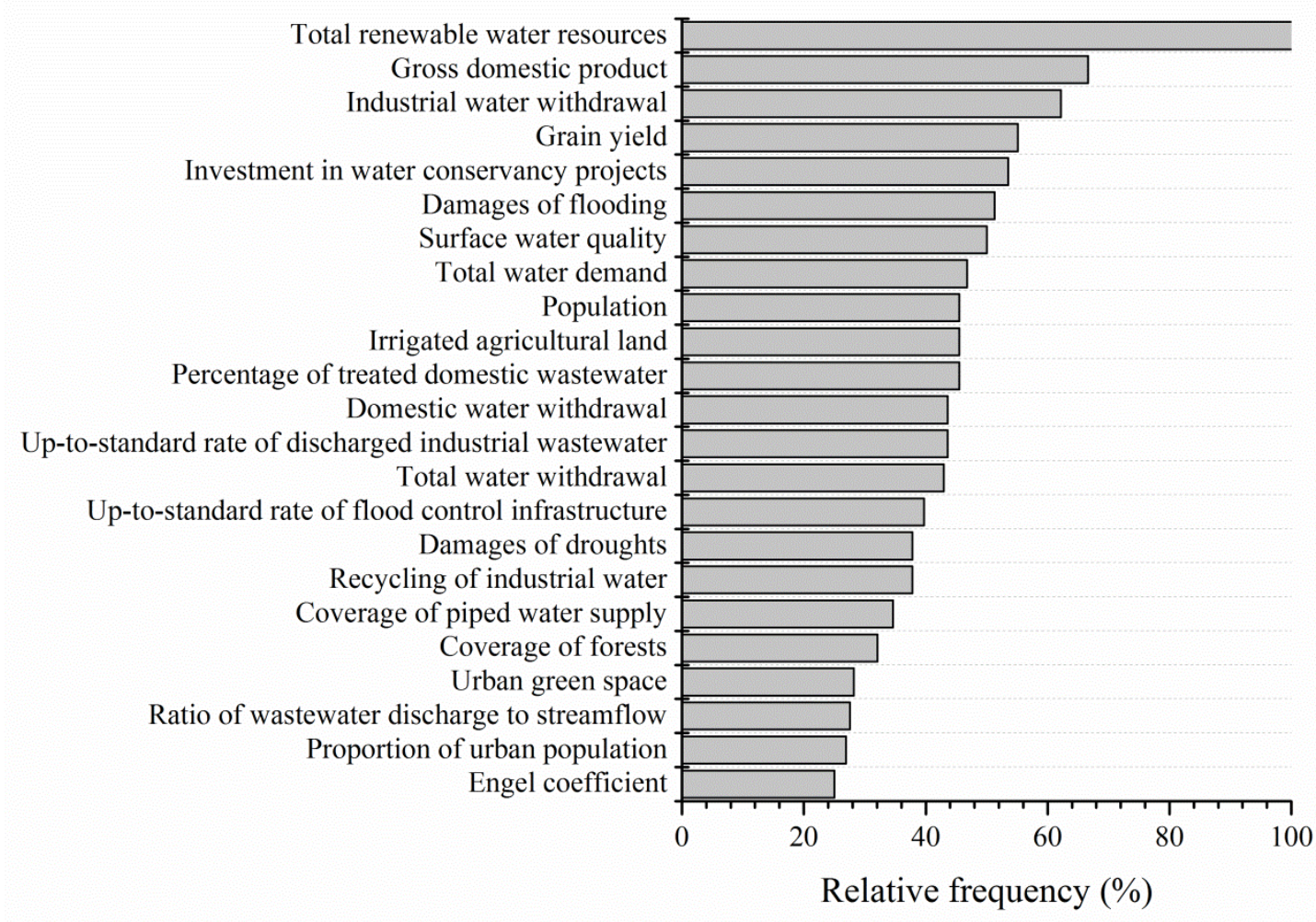

Figure 3 Frequently selected indicators for water security assessment

Due to the great diversity of the indicators for water security assessment, standardization was usually applied before aggregating them into one composite index. Linear interpolation was the most commonly used normalization method [35,36], while some researchers also applied nonlinear approaches to account for, for example, diminishing marginal utility [37,38]. The methods used to assimilate the constituting indicators ranged from the simplest weighted average $[23,38]$ to more sophisticated multi-attribute decision-making methods, e.g. principal component analysis [39], technique for order preference by similarity to ideal solution [40], fuzzy mathematics algorithm [41], gray relational analysis [42], matter element [11], set pair analysis [43], artificial neural network [52], and catastrophe theory [36]. When aggregated, the indicators were, in most cases, assigned different weights, which were usually derived through, among others, the analytical hierarchy process, entropy method, Delphi technique and coefficients of variation $[35,42]$.

\section{Assessment of China's water security at various scales}

The developed water security metrics have been demonstrated in China at different scales to identify the causes of water insecurity, propose strategies to enhance water security, and in some studies, e.g. the previously mentioned third category of studies, evaluate the effectiveness of different strategies. Around $80 \%$ of the previous studies assessed water security status at the scale of administrative regions, e.g. provinces and cities, and another $15 \%$ conducted the assessment at the river basin scale, such as Liaohe river [23], Haihe river [39], Chaohu Lake [44], and Urumqi river [53]. Only a few studies assessed China's water security at the national level. In the early 
2000s, Zhang et al. [54] and Ouyang et al. [6] simulated China's water security status in various development scenarios. Lu et al. [43] and Gong and Yan [45] compared the water security status of concerned cities with the national average following their indicator systems and methods respectively. Zhang et al. [46] and Wang et al. [47] assessed and compared the water security status of 6 major river basins and 31 provinces respectively. Most recently, Li X and Li T [48] assessed China's water security status between 2000 and 2012, while Guo [49] did a similar assessment between 2003 and 2010 with his own indicator system and also provided forecasts into 2020 and 2025.

Current studies on water security assessment in China usually argued that their results agreed well with the situation of the regions. However, a comparison of the results cross different studies would reveal both consistency and inconsistency. For example, Han et al. [59], Tao and Chen [60], and Shen and Xie [40] applied the same indicator system and the same data but different aggregating approaches to assess the water security status in 7 provinces of China, and the rank of the studied provinces were generally comparable although difference existed. However, the rank of the 7 provinces in these 3 studies would differ dramatically from the results of the study by Wang et al. [47], who applied the same indicator system and the same data sources but another aggregating approach to assess the water security status of all the 31 provinces. Specifically, according to $[59,60,40]$, Yunnan and Guangxi were ranked among the 3 provinces with the highest level of water security, while Henan was ranked the fifth out of the 7 provinces. In comparison, Wang et al. [47] found Henan, Yunnan and Guangxi were ranked the $6^{\text {th }}, 21^{\text {st }}$ and $22^{\text {nd }}$ out of the 31 provinces. This cross-validation between different studies has highlighted the impact of the aggregating approach on the results of water security assessment. Similarly, the definition of the indicator system and the data quality may affect the results as well, e.g. between [42] and [47]. Therefore, in spite of the decade-long effort and experience in water security studies in China, robust metrics and methods for water security assessment are still needed for sound decision-making.

\section{Challenges and future research needs}

Water security is usually defined as a "state", so the metrics should describe the essential features of a water-secure society. However, many indicators characterizing the "driver", "pressure", "impact" and "response", referring to the DPSIR framework, were selected by the existing studies in China. This could result from the substitution of "what has been measured" for "what should be measured", e.g. "water quality classes" for "ecological health" [5], which may not be clearly stated in these studies. However, there is still a general lack of clear understanding, not just in China, of "what should be measured" as well as the necessary discrimination and relationships between "what should be measured" and "what has been measured" regarding water security.

Currently, only a few studies on regional water security assessment in China considered the dependency of a region on water resources originating from outside the region or imported virtual water resources. Most studies would possibly be based on the belief that the dependency of a region on external water resources would not constitute a threat to the region in the context of the centralized political system in China. However, the belief would fail to work during emergencies, 
for example, when an accident pollutes the upstream water of the region or an extreme weather event impedes the transportation of food into the region. It is also surprising to find that the studies on China's water security assessment at the national level seldom consider the possible international conflicts of transboundary rivers, probably due to the fact that China, in most cases, is the upstream country. Although some researchers have analyzed the challenge and risk to the international relationships between China and neighboring countries with respect to water resources [56-64], only Yang et al. [65] quantified the risk of water disputes between China and four countries on its southwestern border. In light of this, transboundary water resources or dependency on external water resources should always be considered in water security assessment at different scales in a proper form and in proper detail.

As discussed previously, some Chinese researchers suggest the consideration of public perception in water security assessment, and a handful of studies have included relevant indicators in their indicator systems, e.g. the satisfaction with drinking water quality and water environment [49]. Huang et al. [50] introduced the psychological security coefficients, which were obtained through a questionnaire survey, as part of the weights for the physical aspects of water security before getting the final water security index. Although public perception of water security matters to decision makers, the way how it is incorporated in water security assessment should be further studied, given that public perception of risk does not usually coincide with the actual risk, and the policy implication of the difference between the actual and perceived risk should be elaborated. In addition to understanding public perception, engaging stakeholders in water security assessment, i.e. adopting a participatory approach, could also benefit the design and development of robust metrics and methods [20].

When measuring water security, it is often hard to define the distinct boundary where "security" ends and "insecurity" starts, so the banding system ranging from insecurity to security for each indicator will always be determined with some extent of uncertainties and arbitrariness. That is the reason why many Chinese studies applied the theories and methods of fuzzy mathematics for water security assessment. Depending on the research objectives, however, the regional disparities [47] or temporal progress [48] in water security may be more of an interest than an absolute quantification of water security. Actually, absolute water security can never be achieved due to the ever-changing socio-economic and climatological conditions and ever-growing demand for more security and sustainable utilization of water resources [5]. A pragmatic need is to track the long-term progress in water security status based on relatively consistent and flexible metrics in terms of both the indicators and the banding values.

\section{Conclusions}

Water security has been studied in China since the 1990s, and there have been a great diversity of metrics that were developed and applied for water security assessment at various scales. Although these water security metrics are comparable to those developed by international researchers, there are still critical methodological issues remaining to be addressed, such as the selection, banding and aggregation of indicators, before they could be used for sound decision-making. 


\section{References}

Papers of particular interest, published within the period of review, have been highlighted as:

- of special interest

$\bullet \bullet$ of outstanding interest

1. Global Water Partnership: China's Water Resources Management Challenge: The 'Three Red Lines'. Technical Focus Paper. Global Water Partnership; 2015.

2. Jiang Y: China's water security: Current status, emerging challenges and future prospects. Environ Sci Policy 2015, 54: 106-125.

- This article provides an up-to-date, comprehensive review of China's water security status and the emerging challenges.

3. Hong Y, Luan S: Water security issues in China in the $\mathbf{2 1}^{\text {st }}$ Century. China Environ Manage 1998, 4: 4-7. (in Chinese)

4. Mason N, Calow R: Water Security: From Abstract Concept to Meaningful Metrics. Working Paper 357. Overseas Development Institute; 2012.

5. van Beek E, Arriens WL: Water Security: Putting the Concept into Practice. TEC Background Papers No. 20. Global Water Partnership; 2014.

- This background paper is published by the Global Water Partnership Technical Committee and provides a wealth of information on the definition and components of water security, the relationship between water security and integrated water resources management, and the approaches to quantifying water security in practice.

6. Ouyang Z, Zhao T, Wang R, Soderlund L, Zhang Q: Scenario simulation of water security in China. $J$ Environ Sci 2004, 16: 765-769.

7. Cheng J, Yang X, Wei C, Zhao W: Discussion on water security. China Water Resour 2004, 1: 21-23. (in Chinese)

8. Chen S: Analysis on the definition of water security. China Water Resour 2004, 17: 13-15. (in Chinese)

9. Lu M, Zhang H, Song T, Qiu Y: Theory and research methodology of regional water security. Yellow River 2005, 27: 6-8. (in Chinese)

10. Zhang X, Xia J, Jia S: Definition of water security and its assessment using water poverty index. Resour Sci 2005, 25: 145-149. (in Chinese)

11. Li F, Wang R, Huang J, Yu Q: Synthetic evaluation of water security in West China by multi-index matter-element. Arid Zone Res 2006, 23: 269-274. (in Chinese)

12. Dong Q, Liu X: Risk assessment of water security in Haihe River Basin during drought periods based on D-S evidence theory. Water Sci Eng 2014, 7: 119-132.

13. Gu S, Hu Y: Water security: Connotations, issues and strategies. China Water Resour 2014, 10: 1-3. (in Chinese)

14. Global Water Partnership: Towards Water Security: A Framework for Action. Global Water Partnership; 2000.

15. Asian Development Bank. Asian Water Development Outlook 2013: Measuring water security in Asia and the Pacific. Asian Development Bank; 2013.

•• This report develops a water security framework with five key dimensions, i.e. household water security, economic water security, urban water security, environmental water security, and resilience to water-related disasters, and provides the first quantitative and comprehensive view of 
water security in the Asia-Pacific region.

16. United Nations University: Water Security \& the Global Water Agenda: A UN-Water Analytical Brief. United Nations University; 2013.

17. Grey D, Sadoff CW: Sink or Swim? Water security for growth and development. Water Policy 2007, 9: 545-571.

18. OECD: Water Security for Better Lives, OECD Studies on Water. OECD Publishing; 2013.

19. Gu S, Li W: General ideas for building national water security system. China Water Resour 2015, 9: 3-5. (in Chinese)

- This article is published by two researchers from the Development Research Center of the State Council, a major think-tank of the central government of China, and they define six major components of water security, including water resources, water environment, aquatic ecosystems, water infrastructure, safe drinking water, and peaceful and stable international relationships.

20. Global Water Partnership: Proceedings from the GWP workshop: Assessing water security with appropriate indicators. Global Water Partnership; 2014.

-• This publication provides gives up-to-date information and approaches regarding water security metrics from several countries and regions, including Brazil, Canada, Netherlands, Spain, $\mathrm{UK}$, and the Asia-Pacific region.

21. Han Q: An exploration on theory and methodology of strategic environmental assessment of water security in Hainan Province. Master Thesis. South China University of Tropical Agriculture; 2006. (in Chinese)

22. Tong F, Dong Z: Water security scenario analysis: Methodology and a case study. In Advances in Water Resources and Hydraulic Engineering. Edited by Zhang C, Tang H. Springer; 2009: 307-313.

23. Wang L: Study on water security assessment of Liao River Basin. Master Thesis. Dalian University of Technology; 2005. (in Chinese)

24. Song R: Research on the system dynamics simulation and evaluation of regional water security. Master Thesis. Hefei University of Technology; 2009. (in Chinese)

25. Dou M, Zhang H, Wang C, Jin M: Research on water security regulation modelling driven by development mode. Syst Eng Theory Pract 2015, 35: 2442-2448. (in Chinese)

- This article develops a system dynamics model and simulates the water security status of Zhengzhou city in different scenarios of socio-economic development and water resources management.

26. Xia J, Zhu Y: The measurement of water resources security: A study and challenge on water resources carrying capacity. $J$ Nat Resour 2002, 17: 262-269. (in Chinese)

27. Zhang G, Wang L, Dong J: Time-series analysis in water security assessment of Ji'nan city based on entropy weight. Res Soil Water Conserv 2008, 15: 131-134. (in Chinese)

28. Jin C, Gong L: On the Lanzhou city water security assessment based on the pressure-state-response model. In 2011 International Conference on Energy and Environment. IEEE; 2011: 36-39. (In Chinese)

29. Zhang G, Li S, Wang H: Application of variable fuzzy recognition model to evaluate Shanxi's water security. Resour Ind 2015: 95-101. (in Chinese)

30. Xiang H: Research on construction and application of index system for regional water security assessment. Master Thesis. Jinan University; 2011. (in Chinese)

31. Liu L, Tang D, Chen T: Assessment on the water security of Zhangye based on the DPSIR 
model. In 2012 IEEE fifth International Conference on Advanced Computational Intelligence. IEEE; 2012: 850-855.

32. Liu D, Zhao Q, Bai X: Application of water poverty index in regional water security evaluation. J Irrig Drain 2009, 28: 55-58. (in Chinese)

33. Gong L, Jin C: Urban water security evaluation system based on water poverty index. $J$ Hydroelectr Eng 2014, 33: 84-90. (in Chinese)

- This article develops an indicator system for water security assessment based on the framework of water poverty index and applies it to assess the water security status of 14 cities in Gansu Province.

34. Lei H, Pan H, Liu X, Han Y, Xu J: Evaluation on the regional water security based on virtual water theory and fuzzy-AHP model. J Irrig Drain 2011, 30: 123-127. (in Chinese)

35. Xiao S, Li J, Xiao H, Liu F: Comprehensive assessment of water security for inland watersheds in the Hexi Corridor, Northwest China. Environ Geol 2008, 55: 369-376.

36. Yang F, Shao D, Xiao C, Tan X: Assessment of urban water security based on catastrophe theory. Water Sci Technol 2012, 66: 487-493.

37. Huang Y, Liu X, Shi Z, Fang S, Bai S: Study on assessment methods of evaluate indexes for complex system: Taking urban water safety as case. $J$ China Hydrol 2009, 29: 45-49. (in Chinese)

38. Shao D, Yang F, Xiao C, Tan X: Evaluation of water security: an integrated approach applied in Wuhan urban agglomeration, China. Water Sci Technol 2012, 66: 79-87.

39. Ma H, Liu L, Chen T: Water security assessment in Haihe River Basin using principal component analysis based on Kendall $\tau$. Environ Monit Assess 2010, 163: 539-544.

40. Shen Y, Xie J: Fuzzy matter-element model for evaluating of water safety based on entropy weight and TOPSIS and application. Syst Eng 2014, 32: 143-148. (in Chinese)

41. Liu G: Study on the water security assessment model and the corresponding countermeasures. Master Thesis. Shandong University; 2005. (in Chinese)

42. Jia X, Li C, Cai Y, Wang X, Sun L: An improved method for integrated water security assessment in the Yellow River basin, China. Stoch Environ Res Risk Assess 2015, 29: 2213-2227.

- This article showcases the application of several popular methods for water security assessment among Chinese researchers, including technique for order preference by similarity to ideal solution, gray relational analysis, vague sets, matter element, and set pair analysis.

43. Lu M, Zhang Z, Shi Y: Application of set pair analysis to evaluation of water safety. $J$ Hohai Univ (Nat Sci) 2006, 34: 505-508. (in Chinese)

44. Wu K, Jin J, Wei Y, Zhang H: Diagnosis assessment model of watershed water security based on index system. Acta Sci Nat Univ Sunyatseni 2008, 47: 105-113. (in Chinese)

45. Gong L, Yan S: Researches on the set pair analysis based urban water security evaluation. J Lanzhou Jiaotong Univ 2014, 33: 149-153. (in Chinese)

46. Zhang X, Wang X, Mu H, Huang K, Hu X: Application of water security index to the major river basins of China. In Proceedings of the $2^{\text {nd }}$ Youth Science \& Technology Forum of the Chinese Hydraulic Engineering Society. Chinese Hydraulic Engineering Society; 2005: 577-582. (in Chinese)

47. Wang C, Han Y, Ruan B, Xie J: Water safety evaluation for regional development in China. J China Inst Water Resour Hydropower Res 2010, 8: 34-38. (in Chinese) 
48. $\mathrm{Li} \mathrm{X}$, Li T: Water Security evaluation: An empirical analysis based on Chinese macroscopical data from 2000 to 2012. China Rural Water Hydropower 2015, 3: 45-49. (in Chinese)

- This article assesses China's water security status between 2000 and 2012 with an indicator system consisting of 39 indicators.

49. Li C, Meng X: Establishment of city water security evaluation index system from perspective of ecological civilization. Urban Environ Urban Ecol 2014, 27: 5-9. (in Chinese)

50. Huang Y, Xu L, Yin H, Cai Y, Yang Z: Dual-level material and psychological assessment of urban water security in a water-stressed coastal city. Sustainability 2015, 7: 3900-3918.

- This article considers public perception of water security and introduces psychological security coefficients to water security assessment.

51. Lei H, Pan H, Han Y, Wang F: Research on agricultural water security assessment in Zhengzhou city and some counter-measures based on virtual water theory. China Rural Water Hydropower 2010, 11: 25-28. (in Chinese)

52. $\mathrm{Hu} \mathrm{C}$ : Application of two-hidden layer BP neural network model in evaluation of regional water safety. $J$ Water Resour Water Eng 2013, 24: 196-200. (in Chinese)

53. Zhang R: Evaluation and analysis of water security in Urumqi river basin. $J$ Econ Water Resour 2011, 29: 55-57. (in Chinese)

54. Zhang Q, Ouyang Z, Wang R, Wang X, Min Q, Fu G, Miao H: Modeling water security in China and comparison of the strategies. Adv Water Sci 2002, 13: 569-577. (in Chinese)

55. Guo X: China's water security assessment and countermeasures. Acad J Zhongzhou 2015, 6: 78-82. (in Chinese)

-• This article assesses China's water security status between 2003 and 2010 and also provides forecasts into 2020 and 2025.

56. Sullivan CA, Meigh JR, Giacomello AM, Fediw T, Lawrence P, Samad M, Mlote S, Hutton C, Allan JA, Schulze RE, et al.: The water poverty index: Development and application at the community scale. Nat Resour Forum 2003, 27: 189-199.

57. Sullivan C, Meigh J, Lawrence P: Application of the water poverty index at different scales: A cautionary tale. Water Int 2006, 31: 412-426.

58. Dickson SE, Schuster-Wallace CJ, Newton JJ: Water security assessment indicators: The rural context. Water Resour Manage 2016, 30: 1567-1604.

59. Han Y, Ruan B, Xie J: Multi-objective and multilevel fuzzy optimization model and its application in water security evaluation. Resour Sci 2003, 25: 37-42. (in Chinese)

60. Tao J, Chen X: Establishment of the model of intelligent evaluation methods of water security and its application. Ecol Environ Sci 2010, 19: 1156-1159. (in Chinese)

61. Zhu X, Zhang W, Zhang W: China-ASEAN Cooperation on Water Resource Security. Int Forum 2010, 12: 30-35. (in Chinese)

62. He D, Wu R, Feng Y, Li Y, Ding C, Wang W, Yu D W: China's transboundary waters: new paradigms for water and ecological security through applied ecology. $J$ Appl Ecol 2014, 51: 1159-1168.

63. Guo L, Zhou H, Xia Z, Huang F, Yan B: Water resources security and its countermeasure suggestions in Building Silk Road Economic Belt. China Popul Resour Environ 2015, 25 : 114-121. (in Chinese)

64. Li Z: Climate change and water security in China's periphery. $J$ Int Stud 2015, 36: 37-55. 
(in Chinese)

65. Yang L, Zhang R, Hong M, Liu J, Song C: A risk assessment of water safety of the southwestern border of China based on the cloud model. Resour Environ Yangtze Basin 2014, 23(Supp.1): 1-5. (in Chinese)

- This article is the only one that quantifies the risk of water disputes between China and neighboring countries with regard to transboundary rivers. 